\title{
Substrates and Protected Environments in the Formation of Mouriri elliptica Mart Seedlings
}

\author{
Josiane S. Salles ${ }^{1}$, Alexandre H. F. de Lima ${ }^{1}$, Edilson Costa $^{1}$, Fábio Steiner ${ }^{1}$, Bruna L. B. da Silva ${ }^{1}$, \\ Flávio F. da S. Binotti ${ }^{1}$, Gustavo H. da C. Vieira ${ }^{1} \&$ Andreia F. G. O. de Souza ${ }^{1}$ \\ ${ }^{1}$ Department of Vegetable Ambiance, State University of Mato Grosso do Sul, Cassilândia, MS, Brazil \\ Correspondence: Josiane S. Salles, Department of vegetable ambiance, State University of Mato Grosso do Sul, \\ Cassilândia, MS, Brazil. Tel: 55-679-8159-2907. E-mail: josi_souzasalles@hotmail.com
}

\author{
Received: February 11, $2019 \quad$ Accepted: March 14, $2019 \quad$ Online Published: May 15, 2019 \\ doi:10.5539/jas.v11n6p281 URL: https://doi.org/10.5539/jas.v11n6p281
}

The research is financed by Capes, CNPq, and Fundect.

\begin{abstract}
The successful establishment of a forest restoration program depends of the seedling quality, and the choice of substrate and growing environment plays a significant role in the production of high-quality seedlings. A study was conducted to evaluate the production of croada seedlings (Mouriri elliptica Mart.) grown in thirteen substrate combinations and subjected to two production nurseries constructed with black shading screen

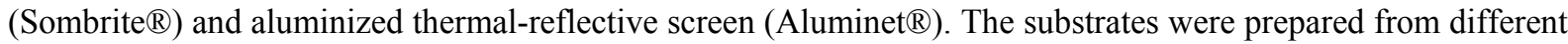
proportions of bovine manure, soil, vermiculite, and sand. In each protected environment, the thirteen different substrate compositions were arranged in a completely randomized design with five replicates of the five seedlings each. Because there was no replication of the cultivation environments, the joint analysis was carried out, allowing the comparison of the environments in the factorial scheme $2 \times 13$ (two environments $\times$ thirteen substrates). Growth and quality of seedlings were measured at 188 days. Seedling production environment has no effect on the germination and emergence process of the seedlings, but the growth and quality of the seedlings can be improved when grown in the nursery with black shading screen. Substrates containing low proportion of bovine manure (from 10 to $30 \%$ ) and high proportion of vermiculite (from 30 to $40 \%$ ) resulted in high-quality croada seedlings.
\end{abstract}

Keywords: bovine manure, croada, plant environment, soil, vermiculite

\section{Introduction}

The Brazilian tropical savanna region (Cerrado) occupies an area of 204 million hectares of Central Brazil, representing about $23 \%$ of the national territory and has one of the most extensive biodiversity of Brazilian fauna and flora. Over four thousand identified local plant species, including almost all of the herbaceous species, are thought to be endemic to the Cerrado region (Ferreira et al., 2017). Among the native fruit species of this region, Mouriri elliptica Mart. have been widely exploited by extractive and predatory activity (Cardoso, Cardoso \& Brito, 2015), which has threatened their preservation and natural propagation in the Cerrado. Thus, it is necessary to intensify the researches with this species to avoid its extinction and ensure its preservation.

Mouriri elliptica Mart., commonly known in Brazil as "croada", "croadinha", "coroa de frade", "puçá" or "puçazeiro", is a perennial tropical fruit tree of the family Melastomataceae, typical of the Brazilian Cerrado (D. B. Silva, A. S. Silva, Junqueira, \& Andrade, 2001). It produces nutritious fruits that contain high levels of antioxidant compounds, which can be consumed in natura or processed into juices, jellies, jams, and ice creams (Rufino et al., 2010). This non-traditional fruit species has significant potential for food and medicine use (Silva et al., 2001) and can be used in the restoration and preservation programs of forest areas. However, studies on the appropriate technologies for the production of croada seedlings are scarce.

The successful establishment of a forest plantation for commercial or conservation purposes depends on the seedling quality produced (Grossnickle \& MacDonald, 2018), and the choice of substrate and growing environment conditions plays a significant role in the production of high-quality seedlings (Costa, Dias, Lopes, Binotti, \& Cardoso, 2015; Arrua, Costa, Bardiviesso, Nascimento, \& Binotti, 2016; Silva, Costa, Salles, Binotti, 
\& Benett, 2018). The quality of seedling is important for obtaining vigorous plants in the field. The production of quality seedlings requires cultivation techniques in protected environments capable of providing ideal conditions for the adequate growth of the species in a relatively short period of time (L. C. Oliveira, Costa, A. D. Oliveira, \& Jorge, 2014; Silva, Nascimento, Andrade, Baracuhy, \& Lima, 2014). According to Grossnickle and MacDonald (2018), the shoot and root system of the seedlings must be large enough and in balance so that the seedlings have a high probability of establishing and competing successfully in the field.

The production of seedlings in protected environments can improve the quality and sanity of the plants due to the improvement of environmental conditions such as temperature, humidity, and light intensity during all seasons of the year. Silva et al. (2018) studied the initial growth of achachairu seedlings (Garcinia humilis Vahl.) in two production environments with $50 \%$ shading, showed that nursery with aluminized thermal-reflective screen produced better quality seedlings when compared to the nursery with black shading screen. However, when poorly managed, these protected nurseries can cause adverse effects, such as high heating or low light intensity, which impairs plant growth. Indeed, Campos and Uchida (2002) showed that the production of jatoba (Hymenaea courbaril L.) in a seedling production nursery with $70 \%$ shading screen impaired plant growth. Therefore, studies that aim to identify the best protected nursery for the production of croada seedlings are important to optimize growth and quality of the seedlings.

The substrate is another factor that influences the quality of the forest species and fruit tree seedlings. The substrate should provide adequate physical, chemical and biological conditions for seedling emergence and growth, such as good aeration, water retention, nutrient availability, and pathogen free (Santos, Costa, Leal, Nardelli \& Souza, 2011). Each fruit tree species responds differently to the composition of substrate used, and studies aiming to identify the best combinations of material in the substrate composition are important to improve the growth and quality of the seedlings. Arrua et al. (2016) evaluating different substrates for the production of mangaba seedlings (Hancornia Speciosa Gomez) under two protected environments, reported that the mixture of bovine manure: soil: vermiculite: sand (2:3:4:1) resulted in better quality seedlings in the seedling nursery with aluminized thermal-reflective screen, whereas in the nursery with black shading screen the growth of plants was enhanced with mixture of bovine manure: soil: vermiculite: sand (1:3:2:4). The use of substrate based on the mixture of soil: sand: bovine manure (1:2:1) improved the growth and quality of jatoba seedlings (Carvalho Filho, Arrigoni-Blank, Blank, \& Rangel, 2003).

An improved understanding of appropriate technologies for the production of croada seedlings is essential to contribute to the preservation of the species and to expand commercial planting and forest restoration programs. This study aimed to evaluate the effects of seedling production nurseries constructed with black shading screen or aluminized thermal-reflective screen, and thirteen substrate combinations for the production of croada seedlings (Mouriri elliptica Mart.).

\section{Material and Methods}

\subsection{Plant Material and Growth Conditions}

The experiments were conducted at the State University of Mato Grosso do Sul (UEMS), in Cassilândia, MS, Brazil ( $19^{\circ} 07^{\prime} 21^{\prime \prime} \mathrm{S}, 51^{\circ} 43^{\prime} 15^{\prime \prime} \mathrm{W}$, and $516 \mathrm{~m}$ altitude), from November 2014 to May 2015 . The regional climate according to the Köppen classification is Aw, characterized as tropical climate with hot summers and a tendency towards high rainfall levels, and dry winters, with a dry season between May and September. The 30-year mean annual temperature is $24.1{ }^{\circ} \mathrm{C}$ with a July minimum of $16.4{ }^{\circ} \mathrm{C}$ and a January maximum of $28.6{ }^{\circ} \mathrm{C}$, and mean annual rainfall of 1,520 $\mathrm{mm}$ (INMET, 2019).

Seeds of Mouriri elliptica ("croada") were extracted from mature fruits collected from trees established in a savannah area of the municipality of Alcinópolis, located in the north region of the State of Mato Grosso do Sul, Brazil (18 $16^{\prime} 59^{\prime \prime} \mathrm{S}, 53^{\circ} 40^{\prime} 235^{\prime \prime} \mathrm{W}$, and altitude of $440 \mathrm{~m}$ ), during the rainy season, in November 2014 . The seeds were extracted by hand, washed in tap water and placed to dry in the shade for a period of 7 days.

Seeds were then sown on November 22, 2014, in black polyethylene bags of $15 \times 25 \mathrm{~cm}(1.8 \mathrm{~L})$, filled with different substrates. The substrates were formulated with different combinations of bovine manure, soil, vermiculite, and sand, as shown in Table 1. Two croada seeds were sown per container at $2 \mathrm{~cm}$ depth, and after the establishment, they were thinned to one plant per container. 
Table 1. Substrates formulated from different proportions (v:v) of bovine manure (M), soil (So), medium grain vermiculite (MV), fine grain vermiculite (FV) and sand $(\mathrm{Sa})$

\begin{tabular}{|c|c|c|c|c|c|}
\hline Substrates & M (\%) & So (\%) & MV (\%) & FV (\%) & $\mathrm{Sa}(\%)$ \\
\hline $\mathrm{S} 1$ & 50 & 30 & 10 & 10 & 0 \\
\hline S2 & 40 & 30 & 10 & 10 & 10 \\
\hline S3 & 30 & 30 & 10 & 10 & 20 \\
\hline S4 & 20 & 30 & 10 & 10 & 30 \\
\hline S5 & 10 & 30 & 10 & 10 & 40 \\
\hline S6 & 50 & 30 & 10 & 0 & 10 \\
\hline S7 & 30 & 30 & 10 & 20 & 10 \\
\hline S8 & 20 & 30 & 10 & 30 & 10 \\
\hline S9 & 10 & 30 & 10 & 40 & 10 \\
\hline $\mathrm{S} 10$ & 50 & 30 & 0 & 10 & 10 \\
\hline S11 & 30 & 30 & 20 & 10 & 10 \\
\hline $\mathrm{S} 12$ & 20 & 30 & 30 & 10 & 10 \\
\hline S13 & 10 & 30 & 40 & 10 & 10 \\
\hline
\end{tabular}

Before use, the fresh bovine manure was subjected to aerobic composting for 30 days. The composted material was then dried, homogenized, and sifted through a $3.70 \mathrm{~mm}$ mesh. The soil was collected from the 0 to $40 \mathrm{~cm}$ depth layer in an Arenic Entisol with $140 \mathrm{~g} \mathrm{~kg}^{-1}$ of clay, $50 \mathrm{~g} \mathrm{~kg}^{-1}$ of silt, and $810 \mathrm{~g} \mathrm{~kg}^{-1}$ of sand. The vermiculite and sand were purchased from commercial companies. Bovine manure and soil were chemically characterized as shown in Table 2.

Table 2. Chemical characteristics of the bovine manure and soil used in the composition of substrates

\begin{tabular}{lll}
\hline Characteristic & Bovine manure & Soil \\
\hline pH in water & 5.8 & 4.4 \\
Organic matter $\left(\mathrm{g} \mathrm{kg}^{-1}\right)$ & 200.0 & 5.0 \\
Carbon:Nitrogen ratio & $12: 1$ & n.d. \\
Total nitrogen $\left(\mathrm{g} \mathrm{kg}^{-1}\right)$ & 9.0 & n.d. \\
Phosphorus $\left(\mathrm{mg} \mathrm{kg}^{-1}\right)$ & $1,300.0$ & 9.0 \\
Potassium $\left(\mathrm{mg} \mathrm{kg}^{-1}\right)$ & 800.0 & 39.0 \\
Calcium $\left(\mathrm{mg} \mathrm{kg}^{-1}\right)$ & 3000.0 & 320.0 \\
Magnesium $\left(\mathrm{mg} \mathrm{kg}^{-1}\right)$ & $1,000.0$ & 72.0 \\
Sulfur $\left(\mathrm{mg} \mathrm{kg}^{-1}\right)$ & 200.0 & 5.4 \\
Copper $\left(\mathrm{mg} \mathrm{kg}^{-1}\right)$ & 18.0 & 0.4 \\
Iron $\left(\mathrm{mg} \mathrm{kg}^{-1}\right)$ & $12,103.0$ & 30.0 \\
Manganese $\left(\mathrm{mg} \mathrm{kg}^{-1}\right)$ & 204.4 & 8.8 \\
Zinc $(\mathrm{mg} \mathrm{kg}$ & 53.0 & 0.3 \\
Sodium $\left(\mathrm{mg} \mathrm{kg}^{-1}\right)$ & 624.0 & 0.0 \\
\hline
\end{tabular}

Note. n.d.: not determined.

After sowing, the plastic bags were taken to the production environments. The two protected environments used for the production of croada seedlings were: (i) agricultural shading screenhouse with galvanized steel structure, measuring $8.00 \mathrm{~m}$ width by $18.00 \mathrm{~m}$ length and $3.50 \mathrm{~m}$ high, closing at 45 degrees, with black shading screen (Sombrite ${ }^{\circledR}$ ) on the sides and roof providing $50 \%$ of shade (A1); and (ii) agricultural shading screenhouse with galvanized steel structure, measuring $8.00 \mathrm{~m}$ width by $18.00 \mathrm{~m}$ length and $4.00 \mathrm{~m}$ high, closing at 90 degrees, with black shading screen on the sides and aluminized thermal-reflective screen (Aluminet ${ }^{\circledR}$ ) on the roof both providing $50 \%$ of shade (A2). The seedlings were watered daily. The irrigation was performed with manual watering, trying not to soak the substrates and to maintain them inadequate conditions for root development (field capacity). The seedlings production was 188 days.

The data of air temperature $\left({ }^{\circ} \mathrm{C}\right)$, relative humidity $(\%)$, global solar radiation $\left(\mathrm{W} \mathrm{m}^{-2}\right)$, and total and diffuse photosynthetically active radiation $\left(\mu \mathrm{mol} \mathrm{m} \mathrm{m}^{-2}\right.$ ) were gathered daily using a GP2 Data Logger (Delta-T Devices Ltd., Burwell, Cambridge, UK) installed within the seedling production environments. The system was 
programmed to perform readings at 10 -second intervals with averages every minute. For the radiations, the daily average was calculated from 8:00 to 18:00 hours. Data collected during the experiments are shown in Table 3 .

Table 3. Average monthly values of temperature $\left({ }^{\circ} \mathrm{C}\right)$, relative air humidity (\%), total and diffuse photosynthetically active radiation $\left(\mu \mathrm{mol} \mathrm{m} \mathrm{m}^{-2} \mathrm{~s}^{-1}\right.$, and global solar radiation $\left(\mathrm{W} \mathrm{m}^{-2}\right)$ in full sunlight, and inside the seedling production environments constructed with black shading screen (Sombrite ${ }^{\circledR}$ ) and aluminized thermal-reflective screen (Aluminet ${ }^{\circledR}$ ), both providing $50 \%$ of shade, during the months of November 2014 to May 2015. Cassilândia, MS, Brazil

\begin{tabular}{|c|c|c|c|c|c|c|c|c|}
\hline \multirow{2}{*}{ Environments } & \multicolumn{8}{|c|}{ Month/Year } \\
\hline & Nov.14 & Dec.14 & Jan.15 & Feb.15 & Mar.15 & Apr.15 & May.15 & Average \\
\hline \multicolumn{9}{|c|}{ Temperatura $\left({ }^{\circ} \mathrm{C}\right)$} \\
\hline Sombrite $^{\circledR}$ & 25.5 & 24.5 & 24.8 & 21.6 & 21.4 & 20.9 & 22.6 & 23.0 \\
\hline Aluminet ${ }^{\circledR}$ & 25.7 & 24.4 & 24.7 & 21.7 & 21.6 & 21.1 & 23.2 & 23.2 \\
\hline Full sunlight & 25.6 & 24.7 & 25.0 & 21.6 & 21.3 & 20.7 & 23.0 & 23.1 \\
\hline \multicolumn{9}{|c|}{ Relative air humidity (\%) } \\
\hline Sombrite ${ }^{\circledR}$ & 69 & 77 & 75 & 70 & 67 & 60 & 52 & 67 \\
\hline Aluminet ${ }^{\circledR}$ & 70 & 81 & 78 & 71 & 68 & 65 & 51 & 69 \\
\hline Full sunlight & 67 & 77 & 73 & 68 & 66 & 64 & 50 & 67 \\
\hline \multicolumn{9}{|c|}{ Diffuse photosynthetically active radiation $\left(\mu \mathrm{mol} \mathrm{m}^{-2} \mathrm{~s}^{-1}\right)$} \\
\hline Sombrite $^{\circledR}$ & 205 & 182 & 148 & 160 & 153 & 152 & 124 & 160 \\
\hline Aluminet $^{(B)}$ & 208 & 201 & 240 & 230 & 198 & 170 & 148 & 200 \\
\hline \multicolumn{9}{|c|}{ Total photosynthetically active radiation $\left(\mu \mathrm{mol} \mathrm{m}^{-2} \mathrm{~s}^{-1}\right)$} \\
\hline Sombrite $\left.^{(}\right)$ & 267 & 359 & 459 & 409 & 390 & 381 & 277 & 363 \\
\hline Aluminet ${ }^{\circledR}$ & 265 & 368 & 466 & 394 & 386 & 381 & 310 & 367 \\
\hline \multicolumn{9}{|c|}{ Global solar radiation $\left(\mathrm{W} \mathrm{m}^{-2}\right)$} \\
\hline Sombrite $^{\circledR}$ & 127 & 168 & 216 & 192 & 183 & 178 & 139 & 172 \\
\hline Aluminet $^{(B)}$ & 136 & 181 & 238 & 208 & 198 & 197 & 163 & 189 \\
\hline Full sunlight & 298 & 458 & 582 & 495 & 447 & 495 & 409 & 455 \\
\hline
\end{tabular}

\subsection{Growth Measurement and Seedling Quality Indexes}

The number of emerged seedlings was recorded weekly, and the final emergence percentage was determined after the 93rd day. The emergence speed index (ESI, in seedling day ${ }^{-1}$ ) was calculated using Maguire's equation (Maguire, 1962):

$$
E S I=\Sigma(n i / t i)
$$

where, $n i$ is the number of emerged seedlings on a given day, and $t i$ is the time in days from the sowing day ( 0 ). The plant height (PH, in cm) was measured using a millimeter ruler at 108, 138 and 188 days after sowing.

At 188 days after sowing, the plants were removed from the containers and washed with water to remove substrate adhered to the roots. The stem diameter (SD, in $\mathrm{mm}$ ) was measured using a digital caliper (Park Tool DC1: $150 \mathrm{~mm}$ ), with an accuracy of $\pm 0.01 \mathrm{~mm}$. The plants then were separated into leaves, stem, and roots, oven-dried at $65^{\circ} \mathrm{C}$ for three days and then weighed.

The results of shoot dry matter (SDM) and root dry matter (RDM) were expressed in grams per plant. From these measurements were calculated total dry matter (TDM), shoot:root dry matter ratio, height:diameter ratio, height:shoot dry matter ratio and Dickson quality index (Dickson, Leaf, \& Hosner, 1960):

$$
\begin{gathered}
S R R=\text { Shoot dry matter }(\mathrm{g}) / \text { Root dry matter }(\mathrm{g}) \\
H D R=\text { Plant height }(\mathrm{cm}) / \text { Stem diameter }(\mathrm{mm}) \\
H S R=\text { Plant height }(\mathrm{cm}) / \text { Shoot dry matter }(\mathrm{g}) \\
D Q I=T D M /(S R R+H D R)
\end{gathered}
$$

\subsection{Experimental Design and Statistical Analysis}

Each protected environment was considered an individual experiment. In each one, the thirteen different substrate compositions were arranged in a completely randomized design with five replicates of the five seedlings each. The protected environments were available by a factorial scheme $2 \times 13$ (two environments $\times$ 
thirteen substrates) when the ratio between the higher and minor mean square of the individual experiment was less than 7.0 (Banzatto \& Kronka, 2013).

The data were subjected to analysis of variance (F-test, $p=0.05$ ). The means of protected environments were compared by the $\mathrm{F}$ and substrates were compared by the Scott-Knott test, both at the $5 \%$ probability level. All analyses were performed by Sisvar software (Ferreira, 2010).

\section{Results and Discussion}

The results of the individual analysis showed that the ratio between the residual mean square (RMSr) of the two production environments was less than 7.0 for all traits measured. Therefore, as there was homogeneity between the residual mean square variances, the comparison of production environments was performed by the joint analysis of the two experiments (Banzatto \& Kronka, 2013).

The emergence speed index (ESI) and emergence percentage (E) of croada seedlings were not affected $(p>0.05)$ by the production environments, while the highest number of leaves and stem diameter was observed in the production environment constructed with black shading screen, as shown in Table 4. This production environment also resulted in higher plant height at 108, 138 and 188 days according to Table 5. These results indicate that the production environment has no effect on the germination and emergence process of the seedlings, but the initial growth of the seedlings can be improved when grown in the nursery with black shading screen.

Table 4. Average values of emergence speed index (ESI), emergence percentage (E), number of leaves (NL) and stem diameter (SD) of croada seedlings (Mouriri elliptica Mart.) grown in different substrate combinations and subjected to two production environments constructed with black shading screen (Sombrite ${ }^{\mathbb{R}}$ ) and aluminized thermal-reflective screen (Aluminet ${ }^{\circledR}$ ), both providing $50 \%$ of shade, during the months of November 2014 to May 2015. Cassilândia, MS, Brazil

\begin{tabular}{|c|c|c|c|c|}
\hline Cause of variation & ESI (seedling day ${ }^{-1}$ ) & $\mathrm{E}(\%)$ & NL (unit plant ${ }^{-1}$ ) & $\mathrm{SD}(\mathrm{mm})$ \\
\hline \multicolumn{5}{|l|}{ Production environments } \\
\hline Black shading screen $\left(\right.$ Sombrite ${ }^{\circledR}$ ) & $0.12 \mathrm{a}$ & $59 \mathrm{a}$ & $15.7 \mathrm{a}$ & $2.70 \mathrm{a}$ \\
\hline Thermal-reflective screen (Aluminet ${ }^{(\mathbb{B}}$ ) & $0.12 \mathrm{a}$ & $55 \mathrm{a}$ & $14.9 \mathrm{~b}$ & $2.51 \mathrm{~b}$ \\
\hline \multicolumn{5}{|l|}{ Substrates } \\
\hline S1 & $0.14 \mathrm{a}$ & $64 \mathrm{a}$ & $16.6 \mathrm{a}$ & $2.66 \mathrm{a}$ \\
\hline S2 & $0.14 \mathrm{a}$ & $63 \mathrm{a}$ & $17.4 \mathrm{a}$ & $2.81 \mathrm{a}$ \\
\hline S3 & $0.13 \mathrm{a}$ & $48 \mathrm{a}$ & $14.5 \mathrm{~b}$ & $2.65 \mathrm{a}$ \\
\hline S4 & $0.12 \mathrm{a}$ & $56 \mathrm{a}$ & $15.1 \mathrm{~b}$ & $2.67 \mathrm{a}$ \\
\hline S5 & $0.10 \mathrm{~b}$ & $61 \mathrm{a}$ & $15.4 \mathrm{~b}$ & $2.62 \mathrm{a}$ \\
\hline S6 & $0.11 \mathrm{~b}$ & $53 \mathrm{a}$ & $16.0 \mathrm{a}$ & $2.62 \mathrm{a}$ \\
\hline S7 & $0.12 \mathrm{a}$ & $57 \mathrm{a}$ & $15.6 \mathrm{a}$ & $2.79 \mathrm{a}$ \\
\hline S8 & $0.11 \mathrm{~b}$ & $57 \mathrm{a}$ & $15.0 \mathrm{~b}$ & $2.52 \mathrm{a}$ \\
\hline S9 & $0.11 \mathrm{~b}$ & $55 \mathrm{a}$ & $14.3 \mathrm{~b}$ & $2.68 \mathrm{a}$ \\
\hline S10 & $0.14 \mathrm{a}$ & $63 \mathrm{a}$ & $16.8 \mathrm{a}$ & $2.61 \mathrm{a}$ \\
\hline S11 & $0.10 \mathrm{~b}$ & $49 \mathrm{a}$ & $14.5 \mathrm{~b}$ & $2.57 \mathrm{a}$ \\
\hline S12 & $0.13 \mathrm{a}$ & $68 \mathrm{a}$ & $15.4 \mathrm{~b}$ & $2.55 \mathrm{a}$ \\
\hline S13 & $0.09 \mathrm{~b}$ & $48 \mathrm{a}$ & $12.8 \mathrm{~b}$ & $2.13 \mathrm{~b}$ \\
\hline $\mathrm{CV}(\%)$ & 29.68 & 22.08 & 14.13 & 10.89 \\
\hline $\mathrm{RMSr}$ & 1.38 & 1.00 & 1.70 & 1.43 \\
\hline$P$ value (Environment $-\mathrm{E})$ & 0.223 & 0.152 & 0.041 & $<0.000$ \\
\hline$P$ value (Substrate $-\mathrm{S}$ ) & 0.048 & 0.170 & $<0.000$ & $<0.000$ \\
\hline$P$ value $(\mathrm{E} \times \mathrm{S}$ interaction $)$ & 0.234 & 0.143 & 0.348 & 0.070 \\
\hline
\end{tabular}

Note. Mean followed by distinct letters for the factors production environments and substrates show significant differences by Scott-Knott and F test, respectively, both at the 5\% probability level. CV: coefficient of variation; RMSr: ratio between the residual mean square of individual analyses of the two production environments. $P$ value: calculated probability. ${ }^{\dagger}$ For abbreviations of the substrates see Table 1. 
Table 5. Average values of plant height (PH) at 108, 138 and 188 days after sowing, and height: diameter ratio (HDR) of croada seedlings (Mouriri elliptica Mart.) grown in different substrate combinations and subjected to two production environments constructed with black shading screen (Sombrite ${ }^{\circledR}$ ) and aluminized thermal-reflective screen (Aluminet ${ }^{\circledR}$ ), both providing $50 \%$ of shade, during the months of November 2014 to May 2015. Cassilândia, MS, Brazil

\begin{tabular}{|c|c|c|c|c|}
\hline Cause of variation & $\mathrm{PH}_{(108 \text { days })}(\mathrm{cm})$ & $\mathrm{PH}_{(138 \text { days })}(\mathrm{cm})$ & $\mathrm{PH}_{(188 \text { days })}(\mathrm{cm})$ & $\operatorname{HDR}(\mathrm{cm} / \mathrm{mm})$ \\
\hline \multicolumn{5}{|l|}{ Production environments } \\
\hline Black shading screen $\left(\right.$ Sombrite ${ }^{\mathbb{B}}$ ) & $7.02 \mathrm{a}$ & $12.95 \mathrm{a}$ & $15.49 \mathrm{a}$ & $5.57 \mathrm{a}$ \\
\hline Thermal-reflective screen (Aluminet ${ }^{(\mathbb{B}}$ ) & $6.61 \mathrm{~b}$ & $12.00 \mathrm{~b}$ & $13.99 \mathrm{~b}$ & $5.78 \mathrm{a}$ \\
\hline \multicolumn{5}{|l|}{ Substrates } \\
\hline S1 & $7.34 \mathrm{a}$ & $13.21 \mathrm{a}$ & $15.56 \mathrm{a}$ & $5.87 \mathrm{a}$ \\
\hline S2 & $7.54 \mathrm{a}$ & $13.85 \mathrm{a}$ & $16.10 \mathrm{a}$ & $5.77 \mathrm{a}$ \\
\hline S3 & $7.06 \mathrm{a}$ & $12.74 \mathrm{a}$ & $15.00 \mathrm{a}$ & $5.68 \mathrm{a}$ \\
\hline S4 & $7.23 \mathrm{a}$ & $12.73 \mathrm{a}$ & $14.18 \mathrm{~b}$ & $5.33 \mathrm{a}$ \\
\hline S5 & $6.59 \mathrm{~b}$ & $12.41 \mathrm{a}$ & $14.84 \mathrm{a}$ & $5.66 \mathrm{a}$ \\
\hline S6 & $7.35 \mathrm{a}$ & $13.52 \mathrm{a}$ & $16.17 \mathrm{a}$ & $6.21 \mathrm{a}$ \\
\hline S7 & $6.98 \mathrm{a}$ & $12.54 \mathrm{a}$ & $15.11 \mathrm{a}$ & $5.44 \mathrm{a}$ \\
\hline S8 & $6.85 \mathrm{a}$ & $12.30 \mathrm{a}$ & $13.97 \mathrm{~b}$ & $5.59 \mathrm{a}$ \\
\hline S9 & $6.32 \mathrm{~b}$ & $11.64 \mathrm{~b}$ & $13.57 \mathrm{~b}$ & $5.10 \mathrm{a}$ \\
\hline $\mathrm{S} 10$ & $7.41 \mathrm{a}$ & $13.44 \mathrm{a}$ & $15.85 \mathrm{a}$ & $6.03 \mathrm{a}$ \\
\hline S11 & $6.56 \mathrm{~b}$ & $12.02 \mathrm{~b}$ & $14.74 \mathrm{a}$ & $5.77 \mathrm{a}$ \\
\hline $\mathrm{S} 12$ & $6.02 \mathrm{~b}$ & $11.64 \mathrm{~b}$ & $14.69 \mathrm{a}$ & $5.77 \mathrm{a}$ \\
\hline S13 & $5.47 \mathrm{~b}$ & $10.14 \mathrm{~b}$ & $11.85 \mathrm{c}$ & $5.56 \mathrm{a}$ \\
\hline $\mathrm{CV}(\%)$ & 16.68 & 16.61 & 14.32 & 12.88 \\
\hline $\mathrm{RMSr}$ & 1.27 & 1.17 & 1.07 & 1.67 \\
\hline$P$ value (Environment- $-\mathrm{E}$ ) & 0.041 & 0.004 & $<0.000$ & 0.113 \\
\hline$P$ value (Substrate- $-\mathrm{S}$ ) & 0.001 & 0.001 & $<0.000$ & 0.116 \\
\hline$P$ value $(\mathrm{E} \times \mathrm{S}$ interaction $)$ & 0.064 & 0.082 & 0.113 & 0.140 \\
\hline
\end{tabular}

Note. Mean followed by distinct letters for the factors production environments and substrates show significant differences by Scott-Knott and F test, respectively, both at the 5\% probability level. CV: coefficient of variation; RMSr: ratio between the residual mean square of individual analyses of the two production environments. $P$ value: calculated probability. ${ }^{\dagger}$ For abbreviations of the substrates see Table 1.

Costa et al. (2015) also obtained better quality baru seedlings (Dipteryx alata Vog.) when grown in an environment with black shading screen in comparison to the environment with aluminized thermal-reflective screen. However, contrary results were reported in achachairu seedlings (Garcinia humilis Vahl.) by Silva et al. (2018), who showed that nursery with aluminized thermal-reflective screen produced better quality seedlings when compared to the nursery with black shading screen.

The highest growth of croada plants in the environment with black shading screen may be due to the fact that this species is adapted to the conditions of shaded environments (Lorenzi, 2009). In this environment, there was a lower incidence of global solar radiation and diffuse photosynthetically active radiation inside the seedling nursery as shown in Table 3, which resulted in more adequate conditions for seedling when compared to the environment with aluminized thermal-reflective screen.

The highest emergence speed indexes of the croada seedlings were obtained with the use of substrates S1, S2, S3, S4, S7, S10, and S12, as shown in Table 4. These results showed that substrates containing the highest proportions of bovine manure (from $20 \%$ to $50 \%$ ) improved the seed speed index; although the seedling emergence percentage was not influenced by the different substrate compositions (Table 4).

The higher emergence speed index obtained with the substrates containing the highest proportions of bovine manure may be due to the greater water retention capacity of this material, which improved the water imbibition of the seeds. The substrate containing bovine manure in its composition was also more suitable for the production of grugru palm seedlings [Acrocomia aculeata (Jacq.) Lodd. ex Mart.] (Costa, Martins, Faria, Jorge, \& Leal, 2014). 
The mean emergence rate of the croada seedlings was $57 \%$, as shown in Table 4 . Similar emergence rate was observed for other species of the Brazilian Cerrado, as for mangaba seeds with 51\% (Arrua et al. 2016) and baru seeds with 66\% (Costa et al., 2014). Evaluating the germination process of croada, Lima et al. (2016) reported that this species has an average emergence rate of $50-60 \%$ due to seed dormancy. These authors showed that the seed emergence rate can be increased by soaking in water for 48 hours. Some species of cerrado fruit trees present problems such as slow and uneven germination (Silva et al., 2001). Therefore, the use of techniques that overcome seed dormancy becomes essential for the production of seedlings.

Substrates containing the highest proportions of bovine manure (i.e., S1, S2, S6, S7, and S10) resulted in the highest number of leaves per plant, according to Table 4. In turn, the substrate S13 containing a low proportion of bovine manure $(10 \%)$ and a higher proportion of medium grain vermiculite $(40 \%)$ produced seedlings with smaller stem diameter when compared to the other substrates (Table 4). These results confirm those reported by Costa et al. (2015), which showed that the substrates containing the lowest proportion of bovine manure (i.e., $10-20 \%$ ) resulted in a lower number of leaves and stem diameter of the baru seedlings.

The higher plant height up to 188 days was obtained with substrates containing the highest proportions of bovine manure as shown in Table 5. These results showed that bovine manure constitutes an excellent material to be used in the formulation of alternative substrates since it is an important source of mineral nutrients for plants according to Table 2. Therefore, substrates containing only $10 \%$ of bovine manure (i.e., S5, S9, and S13) should not be used for the production of croada seedlings because they resulted in lower plant growth (Table 5).

The increase in plant growth, when grown on substrate containing higher proportion of bovine manure, was also reported for grugru palm seedlings (Costa et al., 2014), and achachairu seedlings (Silva et al., 2018). According to Santos et al. (2011), the substrate should provide appropriate physicochemical conditions for seedling emergence and growth, such as adequate aeration, water retention, and nutrient availability.

The height: diameter ratio (HDR) of croada seedlings were not affected $(p>0.05)$ by the different production environments and substrate combinations according to Table 5. Plant height and stem diameter are variables that can be easily measured, and the combination of these morphological characteristics can be used to measure the seedling quality in the nurseries (Tsakaldimi, Ganatsas, \& Jacobs, 2012). Therefore, the height: diameter ratio has been considered one of the most important parameters to estimate the quality and survival of the seedlings in the field.

In general, a value of HDR less than 6.0 indicates that the plant is more vigorous and rustic with a higher probability of survival after planting in the field (Grossnickle \& MacDonald, 2018). On the other hand, a value greater than 6.0 is not desirable because it is an indication that the plant is etiolated. Therefore, based on this inference, it can be seen that the croada seedlings produced in the S6 and S10 substrates had a ratio slightly less than 6.0, indicating the stretching of the plants (Table 5). On the other hand, that the other substrates produced croada seedlings with the best indices of rusticity. Gomes and Paiva (2011) explain that the lower the RAM, the seedling will have a greater capacity for survival in the field, besides being a more lignified seedling.

The shoot dry matter production of the plants grown in the environment with thermal-reflective screen was higher with the use of substrates S4, S5, S7, S8 and S11, whereas in the environment with black shading screen the highest shoot dry matter production was obtained with the substrates S1, S2, S3, S4, S5, S7, S9, and S10 as shown in Table 6. The substrates S4, S5 and S7 containing 10 to $30 \%$ bovine manure and low proportion of medium grain vermiculite resulted in seedlings with higher shoot dry matter in both production environments.

The highest dry matter accumulation of the roots in the environment with black shading screen was obtained with the substrates S2, S3, S5, S7 and S9, while in the environment with thermal-reflective screen the highest root dry matter was obtained with the substrates S4, S5, S7, S8, S9, S10 and S11 (Table 6). In general, substrates containing less than $30 \%$ of bovine manure and a low proportion of medium grain vermiculite resulted in seedlings with higher root dry matter accumulation. These results are similar to those obtained in baru seedlings (Costa et al., 2015) and mangaba (Arrua et al., 2016). 
Table 6. Average values of shoot (SDM), root (RDM) and total dry matter (TDM) of croada seedlings (Mouriri elliptica Mart.) grown in different substrate combinations and subjected to two production environments constructed with black shading screen $\left(\right.$ Sombrite $\left.^{(}\right)$) and aluminized thermal-reflective screen (Aluminet ${ }^{\circledR}$ ), both providing $50 \%$ of shade, during the months of November 2014 to May 2015. Cassilândia, MS, Brazil

\begin{tabular}{|c|c|c|c|c|c|c|}
\hline \multirow{2}{*}{ Substrate $^{\dagger}$} & \multicolumn{2}{|c|}{$\operatorname{SDM}(\mathrm{g})$} & \multicolumn{2}{|c|}{ RDM (g) } & \multicolumn{2}{|c|}{ TDM (g) } \\
\hline & Aluminet $^{(\mathbb{R}}$ & Sombrite $^{(\mathbb{B}}$ & Aluminet $^{(B)}$ & Sombrite $^{(\mathbb{R}}$ & Aluminet $^{(\mathbb{B}}$ & Sombrite $^{\mathbb{R}}$ \\
\hline $\mathrm{S} 1$ & $0.92 \mathrm{Bb}$ & $1.28 \mathrm{Aa}$ & $0.71 \mathrm{Ab}$ & $0.80 \mathrm{Ab}$ & $1.63 \mathrm{Bb}$ & $2.08 \mathrm{Aa}$ \\
\hline $\mathrm{S} 2$ & $0.94 \mathrm{Bb}$ & $1.40 \mathrm{Aa}$ & $0.77 \mathrm{Bb}$ & $1.06 \mathrm{Aa}$ & $1.71 \mathrm{Bb}$ & $2.45 \mathrm{Aa}$ \\
\hline S3 & $0.71 \mathrm{Bb}$ & $1.27 \mathrm{Aa}$ & $0.58 \mathrm{Bb}$ & $0.92 \mathrm{Aa}$ & $1.29 \mathrm{Bb}$ & $2.19 \mathrm{Aa}$ \\
\hline S4 & $1.09 \mathrm{Aa}$ & $1.19 \mathrm{Aa}$ & $0.82 \mathrm{Aa}$ & $0.68 \mathrm{Ab}$ & $1.91 \mathrm{Aa}$ & $1.87 \mathrm{Ab}$ \\
\hline S5 & $1.15 \mathrm{Aa}$ & $1.14 \mathrm{Aa}$ & $1.00 \mathrm{Aa}$ & $1.03 \mathrm{Aa}$ & $2.15 \mathrm{Aa}$ & $2.17 \mathrm{Aa}$ \\
\hline S6 & $0.97 \mathrm{Ab}$ & $0.76 \mathrm{Ab}$ & $0.62 \mathrm{Ab}$ & $0.74 \mathrm{Ab}$ & $1.59 \mathrm{Ab}$ & $1.50 \mathrm{Ab}$ \\
\hline S7 & $1.27 \mathrm{Aa}$ & $1.09 \mathrm{Aa}$ & $0.81 \mathrm{Aa}$ & $0.92 \mathrm{Aa}$ & $2.08 \mathrm{Aa}$ & $2.01 \mathrm{Aa}$ \\
\hline S8 & $1.20 \mathrm{Aa}$ & $0.92 \mathrm{Bb}$ & $0.87 \mathrm{Aa}$ & $0.81 \mathrm{Ab}$ & $2.07 \mathrm{Aa}$ & $1.72 \mathrm{Ab}$ \\
\hline S9 & $1.01 \mathrm{Bb}$ & $1.27 \mathrm{Aa}$ & $0.90 \mathrm{Ba}$ & $1.18 \mathrm{Aa}$ & $1.90 \mathrm{Ba}$ & $2.45 \mathrm{Aa}$ \\
\hline S10 & $1.05 \mathrm{Ab}$ & $1.30 \mathrm{Aa}$ & $0.81 \mathrm{Aa}$ & $0.73 \mathrm{Ab}$ & $1.86 \mathrm{Aa}$ & $2.04 \mathrm{Aa}$ \\
\hline S11 & $1.28 \mathrm{Aa}$ & $0.91 \mathrm{Bb}$ & $1.09 \mathrm{Aa}$ & $0.77 \mathrm{Bb}$ & $2.36 \mathrm{Aa}$ & $1.66 \mathrm{Bb}$ \\
\hline S12 & $0.97 \mathrm{Ab}$ & $0.90 \mathrm{Ab}$ & $0.62 \mathrm{Ab}$ & $0.76 \mathrm{Ab}$ & $1.59 \mathrm{Ab}$ & $1.65 \mathrm{Ab}$ \\
\hline S13 & $0.84 \mathrm{Ab}$ & $0.87 \mathrm{Ab}$ & $0.71 \mathrm{Ab}$ & $0.84 \mathrm{Ab}$ & $1.56 \mathrm{Ab}$ & $1.71 \mathrm{Ab}$ \\
\hline CV $(\%)$ & 19.26 & & 21.42 & & 17.29 & \\
\hline $\mathrm{RMSr}$ & 1.36 & & 1.48 & & 1.20 & \\
\hline$P($ Environment-E $)$ & 0.062 & & 0.023 & & 0.016 & \\
\hline$P($ Substrate $-\mathrm{S})$ & 0.001 & & $<0.000$ & & $<0.000$ & \\
\hline$P(\mathrm{E} \times \mathrm{S}$ interaction $)$ & $<0.000$ & & 0.002 & & $<0.000$ & \\
\hline
\end{tabular}

Note. Mean followed by distinct uppercase letters, in the rows between production environments, or distinct lowercase letters, in the columns for the substrates, in each variable, show significant differences by $\mathrm{F}$ and Scott-Knott test, respectively, both at the 5\% probability level. CV: coefficient of variation; RMSr: ratio between the residual mean square of individual analyses of the two production environments. $P$ value: calculated probability. ${ }^{\dagger}$ For abbreviations of the substrates see Table 1.

Seedlings growing in the substrates S1, S2, S3, and S9 presented higher shoot, root and total dry matter in the environment with black shading screen when compared to the environment with aluminized thermal-reflective screen, as shown in Table 6. The highest dry matter accumulation of croada seedlings in the environment with black shading screen was due to the lower light intensity inside the seedling nursery, according to Table 3 , which improved plant growth. Similar results were reported by Costa et al. (2015), which obtained a greater accumulation of dry matter in the baru seedlings exposed to the environment with black shading screen in comparison to the environment with aluminized screen.

However, contrary results were shown for other fruit species of the cerrado, where the environment with aluminized screen resulted in greater dry matter accumulation of the achachairu seedlings (Silva et al., 2018). Each fruit species responds differently to the growing environment of the seedlings, and the light intensity is one of the main factors of the environment that can alter the plant growth rate. Based on the results presented here, it is verified that the croada seedlings have a better adaptation to the environmental conditions of less light intensity.

The shoot: root dry matter ratio (SRR) of croada seedlings was influenced $(\mathrm{p}>0.05)$ by the different production environments and substrate combinations, as shown in Table 7. The SRR of the plants grown in the environment with thermal-reflective screen was higher with the use of substrates S6, S7, S8, and S12, whereas in the environment with black shading screen the highest SRR was obtained with the substrates S1, S4, S5, and S10 (Table 7). It can be observed that in both production environments, the SRR was between 1.0 and 2.0, indicating an adequate dry matter distribution of shoots and roots.

The shoot: root ratio should not exceed 2:1 for most fruit tree species, and is a useful indirect measure of the balance between the transpiration area versus the water absorption area. The shoot and root system of the seedlings must be large enough and in balance so that the seedlings have a high probability of establishing and competing successfully in the field (Grossnickle \& MacDonald, 2018). 
Table 7. Average values of shoot: root dry matter ratio (SRR), height: shoot dry matter ratio (HSR) and Dickson quality index (DQI) of croada seedlings (Mouriri elliptica Mart.) grown in different substrate combinations and subjected to two production environments constructed with black shading screen (Sombrite ${ }^{\mathbb{B}}$ ) and aluminized thermal-reflective screen (Aluminet ${ }^{\mathbb{B}}$ ), both providing $50 \%$ of shade, during the months of November 2014 to May 2015. Cassilândia, MS, Brazil

\begin{tabular}{|c|c|c|c|c|c|c|}
\hline \multirow{2}{*}{ Substrate $^{\dagger}$} & \multicolumn{2}{|c|}{ SRR $\left(\mathrm{g} \mathrm{g}^{-1}\right)$} & \multicolumn{2}{|c|}{$\operatorname{HSR}\left(\mathrm{cm} \mathrm{g}^{-1}\right)$} & \multicolumn{2}{|c|}{ DQI } \\
\hline & Aluminet $^{(B)}$ & Sombrite $^{(\mathbb{B}}$ & Aluminet $^{(B)}$ & Sombrite $^{(B)}$ & Aluminet $^{(B)}$ & Sombrite $^{R}$ \\
\hline S1 & $1.31 \mathrm{Ab}$ & $1.64 \mathrm{Aa}$ & $16.1 \mathrm{Aa}$ & $13.6 \mathrm{Ac}$ & $0.23 \mathrm{Ab}$ & $0.28 \mathrm{Ab}$ \\
\hline S2 & $1.26 \mathrm{Ab}$ & $1.34 \mathrm{Ab}$ & $16.2 \mathrm{Aa}$ & 12.2 Ac & $0.24 \mathrm{Bb}$ & $0.36 \mathrm{Aa}$ \\
\hline $\mathrm{S} 3$ & $1.27 \mathrm{Ab}$ & $1.45 \mathrm{Ab}$ & $19.5 \mathrm{Aa}$ & $13.0 \mathrm{Bc}$ & $0.19 \mathrm{Bb}$ & $0.30 \mathrm{Ab}$ \\
\hline S4 & $1.80 \mathrm{Ab}$ & $1.33 \mathrm{Ba}$ & $12.9 \mathrm{Ab}$ & $13.4 \mathrm{Ac}$ & $0.29 \mathrm{Aa}$ & $0.26 \mathrm{Ab}$ \\
\hline S5 & $1.16 \mathrm{Ab}$ & $1.10 \mathrm{Aa}$ & $14.3 \mathrm{Ab}$ & $13.1 \mathrm{Ac}$ & $0.31 \mathrm{Aa}$ & $0.34 \mathrm{Aa}$ \\
\hline S6 & $1.57 \mathrm{Aa}$ & $1.04 \mathrm{Bb}$ & $16.8 \mathrm{Ba}$ & $22.4 \mathrm{Aa}$ & $0.21 \mathrm{Ab}$ & $0.21 \mathrm{Ab}$ \\
\hline S7 & $1.62 \mathrm{Aa}$ & $1.23 \mathrm{Bb}$ & $11.5 \mathrm{Ab}$ & $14.8 \mathrm{Ab}$ & $0.31 \mathrm{Aa}$ & $0.29 \mathrm{Ab}$ \\
\hline S8 & $1.49 \mathrm{Aa}$ & $1.18 \mathrm{Ab}$ & $11.0 \mathrm{Bb}$ & $16.8 \mathrm{Ab}$ & $0.30 \mathrm{Aa}$ & $0.25 \mathrm{Ab}$ \\
\hline S9 & $1.20 \mathrm{Ab}$ & $1.08 \mathrm{Ab}$ & $14.2 \mathrm{Ab}$ & $10.9 \mathrm{Ac}$ & $0.29 \mathrm{Ba}$ & $0.42 \mathrm{Aa}$ \\
\hline S10 & $1.30 \mathrm{Bb}$ & $1.79 \mathrm{Aa}$ & $13.1 \mathrm{Ab}$ & 14.2 Ac & $0.28 \mathrm{Aa}$ & $0.24 \mathrm{Ab}$ \\
\hline S11 & $1.17 \mathrm{Ab}$ & $1.17 \mathrm{Ab}$ & $12.0 \mathrm{Bb}$ & $17.5 \mathrm{Ab}$ & $0.36 \mathrm{Aa}$ & $0.23 \mathrm{Bb}$ \\
\hline $\mathrm{S} 12$ & $1.56 \mathrm{Aa}$ & $1.25 \mathrm{Ab}$ & $16.5 \mathrm{Aa}$ & $16.3 \mathrm{Ab}$ & $0.22 \mathrm{Ab}$ & $0.24 \mathrm{Ab}$ \\
\hline S13 & $1.19 \mathrm{Ab}$ & $1.09 \mathrm{Ab}$ & $13.5 \mathrm{Ab}$ & $14.5 \mathrm{Ac}$ & $0.23 \mathrm{Ab}$ & $0.26 \mathrm{Ab}$ \\
\hline $\mathrm{CV}(\%)$ & 21.58 & & 25.38 & & 22.45 & \\
\hline $\mathrm{RMSr}$ & 1.63 & & 1.89 & & 1.82 & \\
\hline$P($ Environment-E) & 0.652 & & 0.558 & & 0.102 & \\
\hline$P($ Substrate $-\mathrm{S})$ & 0.003 & & 0.005 & & $<0.000$ & \\
\hline$P(\mathrm{E} \times \mathrm{S}$ interaction $)$ & 0.001 & & 0.002 & & $<0.000$ & \\
\hline
\end{tabular}

Note. Mean followed by distinct uppercase letters, in the rows between production environments, or distinct lowercase letters, in the columns for the substrates, in each variable, show significant differences by $\mathrm{F}$ and Scott-Knott test, respectively, both at the 5\% probability level. CV: coefficient of variation; RMSr: ratio between the residual mean square of individual analyses of the two production environments. $P$ value: calculated probability. ${ }^{\dagger}$ For abbreviations of the substrates see Table 1.

When the seedlings were exposed to the environment with thermal-reflective screen, the height: shoot dry matter ratio (HSR) was significantly higher with the substrates S1, S2, S3, S6, and S10 (Table 7). In the environments with black shading screen, the HSR was significantly greater with the substrate S6 and lower for the substrates S1, S2, S3, S4, S5, S9, S10, and S13 (Table 7).

The Dickson quality index (DQI) of the seedlings grown in the environment with thermal-reflective screen was higher with the use of substrates S4, S5, S7, S8, S9, S10, and S11, whereas in the environment with black shading screen the highest DQI was obtained with the substrates S2, S5, and S9 (Table 7). Among the environments, the substrate S11 produced seedlings of higher DQI in the environment with aluminized thermal-reflective screen, while the substrates S2, S3, and S9 produced seedlings of higher DQI in the environment with black shading screen (Table 7). Substrates S5 and S9 containing only $10 \%$ of bovine manure resulted in seedlings with higher DQI in both production environments.

These results indicate that low proportion of manure in the substrate resulted in a more balanced growth between the shoots and the root system of the seedlings, giving a higher quality of the seedlings. In mangaba seedlings, Arrua et al. (2016) also showed that substrates containing lower proportion of bovine manure resulted in higher quality seedlings, as reported by higher DQI value.

In summary, substrates containing a low proportion of bovine manure (10 to 30\%) and high proportion of vermiculite (30 to $40 \%$ ) resulted in higher quality seedlings. This is an indication that the croada, a species of Cerrado fruit tree, has a low-medium nutrient requirement during the seedling production phase.

\section{Conclusion}

Higher quality croada seedlings are produced in growing environments with black shading screens. Croada plants have a positive growth response with the use of up to $30 \%$ of bovine manure and $40 \%$ vermiculite in the substrate composition. 


\section{Acknowledgements}

This study was financed in part by the Coordenação de Aperfeiçoamento de Pessoal de Nível Superior-Brasil (CAPES)-Finance Code 001. Support also from FUNDECT/PRONEM/CNPq 15/2014; FUNDECT/PPP 05/2011; FUNDECT/PAPOS/PGAC 2016, and CNPq.

\section{References}

Arrua, L. L. C., Costa, E., Bardiviesso, E. M., Nascimento, D. M., \& Binotti, F. F. S. (2016). Protected environments and substrates for mangabeira seedlings (Hancornia Speciosa Gomez) production. Engenharia Agrícola, 36(6), 984-995. https://doi.org/10.1590/1809-4430-eng.agric.v36n6p984-995/2016

Banzatto, D. A., \& Kronka, S. N. (2013). Experimentação agrícola (3rd ed.). Jaboticabal, SP: Funep.

Campos, M. A. A., \& Uchida, T. (2002). Influência do sombreamento no crescimento de mudas de três espécies amazônicas. Pesquisa Agropecuária Brasileira, 37(3), 281-288. https://doi.org/10.1590/S0100-204X200 2000300008

Cardoso, M. R. C., Cardoso, G. C. C., \& Brito, J. M. B. S. (2015). Economia e planejamento do ecoturismo: Estudo de caso no Cerrado brasileiro. Sustentabilidade em Debate, 6(3), 100-115. https://doi.org/10.18472/ SustDeb.v6n3.2015.12699

Carvalho Filho, J. L. S., Arrigoni-Blank, M. F., Blank, A. F., \& Rangel, M. A. S (2003). Produção de mudas de jatobá (Hymenaea courbaril L.) em diferentes ambientes, recipientes e composições de substratos. CERNE, 9(1), 109-118.

Costa, E., Dias, J. G., Lopes, K. G., Binotti, F. F. S., \& Cardoso, E. D. (2015). Telas de sombreamento e substratos na produção de mudas de Dipteryx alata Vog. Floresta e Ambiente, 3(22), 416-425. https://doi.org/10.1590/2179-8087.071714

Costa, E., Martins, R. F., Faria, T. A. C., Jorge, M. H. A., \& Leal, P. A. M. (2014). Seedlings of Acrocomia aculeata in different substrates and protected environments. Engenharia Agrícola, 34(3), 395-404. https://doi.org/10.1590/S0100-69162014000300002

Dickson, A., Leaf, A. L., \& Hosner, J. F. (1960). Quality appraisal of white spruce and white pine seedling stock in nurseries. Forestry Chronicle, 36(1), 10-13. https://doi.org/10.5558/tfc36010-1

Ferreira, D. F. (2010). SISVAR-Sistema de análise de variância (Version 5.3). Lavras, MG: UFLA.

Ferreira, F. G., Machado, E. L. M., Silva-Neto, C. M., Silva Júnior, M. C., Medeiros, M. M., Gonzaga, A. P. D., ... Fagg, J. M. F. (2017). Diversity and indicator species in the cerrado biome, Brazil. Australian Journal of Crop Science, 11(8), 1042-1050. https://doi.org/10.21475/ajcs.17.11.08.pne615

Gomes, J. M., \& Paiva, H. N. (2011). Viveiros florestais: Propagação sexuada. Viçosa, MG: UFV.

Grossnickle, S. C., \& Macdonald, J. E. (2018) Seedling quality: History, application, and plant attributes. Forests, 9(283), 1-23. https://doi.org/10.3390/f9050283

INMET (Instituto Nacional de Meteorologia). (2019). Clima: Gráficos Climatológicos. Retrieved from http://www.inmet.gov.br/portal/index.php?r=clima/graficosClimaticos

Lima, L. R., Rubio-Neto, A., Pereira, F. D., Silva, F. G., Menezes, C. C. E., \& Santana, J. G. (2016). Germination and emergence of Mouriri elliptica Mart., a rare medicinal fruit tree native to the Brazilian Cerrado biome. African Journal of Agricultural Research, 11(5), 400-406. https://doi.org/10.5897/AJAR2015.10444

Lorenzi, H. (2009). Árvores brasileiras: Manual de identificação e cultivo de plantas nativas do Brasil (3rd ed.). Nova Odessa: Plantarum. https://doi.org/10.1590/S0100-39842009000300014

Maguire, J. D. (1962). Speed of germination-aid in selection and evaluation for seedling emergence and vigor. Crop Science, 2(1), 176-177. https://doi.org/10.2135/cropsci1962.0011183X000200020033x

Oliveira, L. C., Costa, E., Oliveira, A. D., \& Jorge, M. H. A. (2014). Emergência do baruzeiro sob ambientes protegidos e substratos. Revista de Agricultura Neotropical, 1(1), 10-16. https://doi.org/10.32404/ rean.v1i1.218

Rufino, M. S. M., Alves, R. E., Brito, E. S., Pérez-Jiménez, J., Saura-Calixto, F., \& Mancini-Filho, J. (2010). Bioactive compounds and antioxidant capacities of 18 non-traditional tropical fruits from Brazil. Food Chemistry, 121(4), 996-1002. https://doi.org/10.1016/j.foodchem.2010.01.037 
Santos, L. C. R., Costa, E., Leal, P. A. M., Nardelli, E. M. V., \& Souza, G. S. A. (2011). Ambientes protegidos e substratos com doses de composto orgânico comercial e solo na formação de mudas de jatobazeiro em Aquidauana-MS. Engenharia Agrícola, 31(2), 249-259. https://doi.org/10.1590/S0100-691620110 00200005

Silva, B. L. B., Costa, E., Salles, J. S., Binotti, F. F. S., \& Benett, C. G. S. (2018). Protected environments and substrates for achachairu seedlings. Engenharia Agrícola, 38(3), 309-318. https://doi.org/10.1590/18094430-eng.agric.v38n3p309-318/2018

Silva, D. B., Silva, A. S., Junqueira, N. T. V., \& Andrade, L. R. M. (2001). Frutas do Cerrado. Brasília, DF: Embrapa Informação Tecnológica.

Silva, E. A., Maruyama, W. I., Oliveira, A. C., \& Bardiviesso, D. M. (2009). Efeito de diferentes substratos na produção de mudas de mangabeira (Hancornia speciosa). Revista Brasileira de Fruticultura, 31(3), 925-929. https://doi.org/10.1590/S0100-29452009000300043

Silva, V. F., Nascimento, E. C. S.; Andrade, L. O., Baracuhy, J. G. V., \& Lima, V. L. A. (2014). Efeito do substrato bovino na germinação de pimenta biquinho (Capsicum chinense) irrigado com água residuária. Revista Monografias Ambientais, 13(5), 3865-3871. https://doi.org/10.5902/2236130814844

Tsakaldimi, M., Ganatsas, P., \& Jacobs, D. F. (2012). Prediction of planted seedling survival of five Mediterranean species based on initial seedling morphology. New Forests, 44(3), 1-13.

\section{Copyrights}

Copyright for this article is retained by the author(s), with first publication rights granted to the journal.

This is an open-access article distributed under the terms and conditions of the Creative Commons Attribution license (http://creativecommons.org/licenses/by/4.0/). 